IZA DP No. 6230

Job Separations and Informality in the Russian Labor Market

Hartmut Lehmann

Tiziano Razzolini

Anzelika Zaiceva

December 2011 


\title{
Job Separations and Informality in the Russian Labor Market
}

\author{
Hartmut Lehmann \\ University of Bologna \\ and IZA \\ Tiziano Razzolini \\ University of Siena \\ and $L A B O R$
}

Anzelika Zaiceva

University of Modena and Reggio Emilia

and IZA

Discussion Paper No. 6230

December 2011

\author{
IZA \\ P.O. Box 7240 \\ 53072 Bonn \\ Germany \\ Phone: +49-228-3894-0 \\ Fax: +49-228-3894-180 \\ E-mail: iza@iza.org
}

\begin{abstract}
Any opinions expressed here are those of the author(s) and not those of IZA. Research published in this series may include views on policy, but the institute itself takes no institutional policy positions.

The Institute for the Study of Labor (IZA) in Bonn is a local and virtual international research center and a place of communication between science, politics and business. IZA is an independent nonprofit organization supported by Deutsche Post Foundation. The center is associated with the University of Bonn and offers a stimulating research environment through its international network, workshops and conferences, data service, project support, research visits and doctoral program. IZA engages in (i) original and internationally competitive research in all fields of labor economics, (ii) development of policy concepts, and (iii) dissemination of research results and concepts to the interested public.
\end{abstract}

IZA Discussion Papers often represent preliminary work and are circulated to encourage discussion. Citation of such a paper should account for its provisional character. A revised version may be available directly from the author. 


\section{ABSTRACT}

\section{Job Separations and Informality in the Russian Labor Market ${ }^{*}$}

In the years 2003-2008 the Russian economy experienced a period of strong and sustained growth, which was accompanied by large worker turnover and rising informality. We investigate whether the burden of informality falls disproportionately on job separators (displaced workers and quitters) in the Russian labor market in the form of informal employment and undeclared wages in formal jobs. We also pursue the issues whether displaced workers experience more involuntary informal employment than workers who quit and whether informal employment persists. We find a strong positive link between separations and informal employment as well as shares of undeclared wages in formal jobs. Our results also show that displacement entraps some of the workers in involuntary informal employment. Those who quit, in turn, experience voluntary informality for the most part, but there seems a minority of quitting workers who end up in involuntary informal jobs. This scenario does not fall on all separators but predominantly on those with low human capital. Finally, informal employment is indeed persistent since separating from an informal job considerably raises the probability to be informal in the subsequent job.

JEL Classification: J64, J65, P50

Keywords: job separations, informality, Russia

Corresponding author:

Hartmut Lehmann

Department of Economics

University of Bologna

Strada Maggiore 45

40125 Bologna

Italy

E-mail: hartmut.lehmann@unibo.it

\footnotetext{
*Forthcoming in: Research in Labor Economics, 2012.

We are grateful to Alexander Muravyev, Fabian Slonimczyk, two anonymous referees and to participants of the IZA workshop "Institutions and Informal Employment in Emerging and Transition Economies" in June 2011 in Bonn for valuable comments and suggestions. The comments and suggestions of one of the editors, Konstantinos Tatsiramos, were particularly helpful in improving the paper. We thank the MacArthur Foundation for financing the informality supplement. Lehmann is also grateful to the Volkswagen Foundation for financial support within the project "The political economy of labor market reform in transition economies: a comparative perspective". We would also like to express our appreciation to Vladimir Gimpelson, Rostislav Kapeliushnikov, Mikhail Kosolapov and Polina Kozyreva for their invaluable help in developing the RLMS displacement and informality supplements.
} 


\section{Job Separations and Informality in the Russian Labor Market}

\section{Introduction}

Russia experienced a period of strong economic growth between 1999 and 2008. This growth, manifesting itself in an average GDP growth rate of roughly 7 percent, was accompanied by substantial worker turnover in the Russian labor market, with annual job separations amounting to up to 20 percent (see Figure 1). Parallel to these large separations rates we see a continuous rise in informal employment and informal activities: the number of informally employed workers rose from roughly 8 million in 1999 to about 12 million in 2008, i.e. from 13 to 18 percent of total employment (Gimpelson and Zudina 2011). Schneider et al. (2010) provide evidence that the shadow economy of Russia is large compared to other transition and emerging economies, amounting to roughly 41 percent of official GDP in 2007.

Even if the shadow economy and informal employment are substantial, it could well be that they afflict predominantly marginal groups of the workforce. The descriptive statistics of dependent employees in 2009 in Table 1 show that the informally employed indeed have a worse labor market history and, in the case of educational attainment, worse characteristics than their formal counterparts. Preceding the job in 2009, informally employed have substantially longer non-employment spells and a far lower share of university graduates. Still, nearly 12 percent of the informally employed have finished university education. What is in addition particularly striking in Table 1 is the lack of divergence regarding the other demographics. Thus rising informal employment is an important phenomenon in the Russian labor market, which is clearly not restricted to marginal groups of the workforce.

The main aim of this paper is to investigate the link between job separations and the incidence of informal employment. The first six rows of Table 1 seem to imply such a link since informal employees have roughly twice the displacement and quit rates of formal employees. In a transition 
economy like the Russian one where informal employment has been growing and where the vast majority of incumbents has a formal employment relationship it might well be that the burden of rising informal employment falls disproportionately on job separators. ${ }^{1}$

We are particularly interested in establishing whether the type of job separation produces a differential impact on informality. In other words, are workers who voluntarily separate from their jobs (quitters) differently affected than their displaced counterparts who lost their jobs involuntarily? We can moot that quitters are less likely to end up in informal employment against their will than displaced workers. Using unique data from a displacement supplement to the Russian Longitudinal Monitoring Survey (RLMS) in 2008 and from an informality supplement to the RLMS in 2009 we are able to test this proposition. We thus can establish important findings about the factors driving the formal-informal divide in the labor market, which have not yet sufficiently been discussed in the literature, by linking mode of job separations and subsequent informal or formal employment. ${ }^{2}$ Our data are detailed enough to investigate the impact of job separations on type of employment across heterogeneous groups of the workforce. We can also analyze whether informality breeds informality, i.e. whether having separated from an informal job raises the likelihood to find oneself subsequently in another informal job.

The scarce empirical literature on informality in transition countries finds that most informal employment relationships are not wanted by the affected workers, especially if they are dependent wage earners. ${ }^{3}$ Given this predominantly involuntary nature of informal employment its incidence might be perceived as a labor market outcome that imposes a cost on displaced workers. This paper

\footnotetext{
${ }^{1}$ In principle rising informal employment could also obtain by changing formal jobs of incumbents into informal ones and by having a high incidence of informal employment for new labor market entrants.

2 Neither the general literature that debates labor market segmentation versus integrated labor markets (e.g. Harris and Todaro 1970 versus de Soto 1990 and Maloney 2004) nor the literature on informality in transition countries (see papers mentioned in footnote 3) do discuss the link between job separations and informality.

${ }^{3}$ See, e.g., Krstic and Sanfey (2007) on Bosnia and Hercegovina, Lehmann and Pignatti (2007) on Ukraine, Bernabè and Stampini (2008) on Georgia and Pagés and Stampini (2007) on several transition countries.
} 
thus contributes to the large literature on the costs of job loss. ${ }^{4}$ The conventional costs that this literature focuses on are foregone earnings due to less employment and less hours worked but also wage penalties upon reemployment. In a companion paper, we find that the monetary costs of job loss in Russia consist in large foregone earnings due to less employment and less hours worked and not in wage penalties upon re-employment (Lehmann et al. 2011).

In addition to these traditional labor market outcomes caused by job loss, researchers have started to look at other outcomes that are related to workers' welfare as well as the welfare of their families. For example, Sullivan and von Wachter (2009) analyze life expectancy as an outcome and establish that displacement at age 40 will shorten the life expectancy of an average worker in the United States by 1 to 1.5 years. Leombruni, Razzolini and Serti (2010) measure the causal effect of displacement on workplace injury rates in Italy, confirming a substantially higher injury rate at subsequent jobs of displaced workers relative to their non-displaced counterparts. Lindo (2011) investigates parental job loss and infant health in the United States. His analysis reveals that husbands' job losses have significant negative effects on infant health. Liu and Zhao (2011) study a similar issue in China, looking at the effects of mass layoffs of parents in the mid-1990s on their children's health. They find that paternal job loss affects children's health negatively while maternal job loss does not show any significant effect. ${ }^{5}$

Adding to this literature we focus on two non-conventional labor market outcomes for the individual displaced worker: apart from informal employment relationships in subsequent jobs we also look at unofficial wage payments in formal sector jobs, which are wide-spread in the Russian economy (Gimpelson and Zudina 2011). Lehmann et al. (2011) provide some preliminary evidence that displaced workers have a higher probability of having their subsequent jobs in the informal sector than

\footnotetext{
${ }^{4}$ For a survey of older studies on the costs of job loss see Kuhn (2002); the most recent studies are summarized, for example, in Hijzen et al. (2010).

5 There are many more studies on the health costs of displacement; this growing literature is discussed in Lindo (2011).
} 
their non-displaced counterparts. The study here exclusively focuses on the link between job separations and informality using various measures of informal employment from different data sources as well as a measure of unofficial wage payments (so called “envelope payments”).

Being able to distinguish between involuntary and voluntary informal employment our study contributes to the debate in the informality literature on the issue of segmented versus integrated labor markets. We thus contribute not only to the literature on displacement but also to the literature on informality.

The remainder of the paper has the following structure. The next section addresses the research questions that we investigate when linking job separations and informal employment relationships, embedding this discussion in the literature on informality, while section 3 discusses the data and definitional issues and provides some descriptive analysis of type of job separations and informality. This is followed by a section, which presents the empirical models and our research approach of testing the link between displacement, quits and informality. These tests are done first for dependent employees only using probit, pooled logit and fixed effect logit models as well as OLS estimation. In a second part they are extended to formal and informal self-employment and non-employment within a multinomial logit framework. Section 5 presents our empirical findings. We find a significant impact of previous displacement and quits on informality, which is robust to different measures of informality. The central results of our analysis show that displacement entraps some of the workers in involuntary informal employment. Those who quit, in turn, experience voluntary informality for the most part, but there seems a minority of quitting workers who read the labor market incorrectly and thus end up in involuntary informal jobs. This scenario of entrapment for the displaced and wrong expectations of some of those who quit does not fall on all the workers who separate but predominantly on workers with low human capital and on those who separate from informal jobs. In a final section we offer some conclusions and policy implications. 


\section{Linking displacement, quits and subsequent informal employment}

The general literature on informality does not discuss a possible link of the mode of separation from jobs on the one hand and the formality or informality of subsequent jobs on the other. The theoretical search and matching macro models, which explicitly include an informal sector, treat separations from jobs as exogeneous. ${ }^{6}$ Micro studies on informal employment, on the other hand, make no distinction between involuntary displacement and voluntary quits (see, e.g., Boeri and Garibaldi, 2006, Bosch and Maloney, 2010).

The scarce literature on informality in transition countries analyzes the generally contentious issue of whether labor markets are segmented and workers are prevented from entering the formal sector, as put forth in an early seminal paper by Harris and Todaro (1970), or whether labor markets are integrated and most workers choose voluntarily the informal sector (see, e.g., De Soto 1990 and Maloney 2004). For Bosnia and Herzegovina Krstic and Sanfey (2007) find segmentation as do Bernabè and Stampini (2008) for Georgia. Lehmann and Pignatti (2007), on the other hand get mixed results for the Ukrainian labor market: while they establish segmentation for dependent employees, they find a two-tier informal self-employment sector, where the lower tier reflects an integrated labor market, i.e. anyone can enter informal activities, while the more remunerative upper tier is segmented, with workers blocked from freely entering this part of informal self-employment. ${ }^{7}$

None of these studies explicitly take into account previous employment, past informality experience or the type of separation from the previous job, which might have an important impact on whether a worker is formally or informally employed in the current job. It is certainly feasible to moot that displaced workers have a higher probability to end up in informal employment against their will. In turn, those who quit may choose an informal employment relationship voluntarily. However, a fraction of those who quit might read the labor market wrong and consequently also they might end up in

\footnotetext{
${ }^{6}$ See, e.g., Kolm and Larsen (2003); Albrecht, Navarro and Vroman (2009); Zenou (2008).

${ }^{7}$ This characterization of informal self-employment goes back to Fields (1990)
} 
informal employment involuntarily. With the data at our disposal we are, therefore, interested to pose the following four research questions:

1. Do job history and past separations matter for subsequent informal employment and the amount of “envelope payments” and are there any differences between voluntary and involuntary separations?

2. Are displaced workers more likely to be "trapped" in informality while those who quit choose it voluntarily?

3. Is the experience of displaced workers and quitters with little human capital different from those with abundant human capital?

4. Is informality persistent, i.e. are workers who separate from informal jobs more likely to be informally employed in their subsequent jobs and are there different likelihoods for those displaced and those who quit from informal jobs?

Answers to these questions allow us to better understand the nature of informal employment and what drives it in the Russian labor market. Thus, the value added of this paper does not only consist in establishing whether informality is an additional important cost of displacement but also sheds light on unresolved questions in the literature regarding the factors driving the formal-informal divide in the labor market. In this regard, our analysis especially contributes to the debate on the nature of labor markets in emerging and transition countries, i.e. whether these labor markets are segmented or integrated. 


\section{Data sources, measurement issues and descriptive analysis}

\subsection{Data sources}

The analysis uses a database that consists of the panel data of the Russian Longitudinal Monitoring Survey (RLMS) for the years 2003 to 2009 and two special supplements. The first supplement is on displacement that was developed by our team in collaboration with Russian scholars and administered to the $17^{\text {th }}$ round of the RLMS between September and December 2008, while the second one on informality, developed by the same group of researchers, was fielded between September and December 2009. The main RLMS data form a well known rich panel data set, which has provided the empirical basis of many important papers on the Russian labor market. We use the main panel data of the years 2003 to 2009 and combine them with the new data from the two supplements.

This study and the two supplements focus on the main job of workers, which in the case of multiple job holding is either the job providing the largest income or the job where the worker deposits his or her labor book. ${ }^{8}$ We also distinguish in our analysis between dependent employees and the selfemployed and entrepreneurs. Following Slonimczyk (this volume), we consider respondents as selfemployed/entrepreneurs if they report to undertake entrepreneurial activities and to be either owners of firms or self-employed individuals who work on their own account with or without employees.

The supplement on displacement provides retrospective information on respondents' job and nonemployment spells over the years 2003 to 2008. We have information on the beginning and the end of each job spell and of each non-employment spell and we are thus able to construct a complete labor market history for all respondents in the indicated period. ${ }^{9}$ The panel element of the supplement also allows us to trace informal employment over time.

\subsection{Separation events: their definition and profile}

\footnotetext{
${ }^{8}$ Respondents in the main RLMS and in the displacement supplement are asked to discuss the job that they themselves consider their main job. This can be understood by the respondents in the two ways mentioned in the text.

${ }^{9}$ We also have information on the actual weekly hours worked, on occupation and the sector of employment as well as on the wage at the beginning and the end of each job.
} 
In order to identify a separation as a quit or a displacement the supplement on displacement provides information on the reason for separating from a job. The possible answers given in the supplement are reproduced in Table A1 and are very much standard in labor force surveys administered in OECD countries. As respondents are told to only give one answer it is relatively straightforward to classify job separations into quits and displacements. ${ }^{10}$ We use the first seven answers in Table A1 to determine a separation as a displacement. These answers all reflect involuntary separations insofar as they occur for reasons, which are extraneous to the worker. Focusing only on the first seven answers gives us a conservative estimate of the displacement rate since it might not be unreasonable to consider the expiring of employment contract or of probation time also a displacement. However, we stick to the narrower definition of displacement when producing the estimates of Figure $1 .^{11}$

The upper panel of Figure 1 shows the estimates of annual quit and displacement rates for the years 2003 to 2008. Quit rates are generally thought to be pro-cyclical and displacement rates countercyclical (Pissarides 1994). This supposition is borne out by the presented quit and displacement rates. Since the years 2003-2008 are a boom period we see very large quit rates that are between four to five times larger than the displacement rates. The latter rates hover between two and three percent and are thus not negligible but on the lower end of the spectrum that we observe in OECD countries (Kuhn 2002). Only a small portion of displacements are caused by plant or firm closure, the vast majority are due to redundancies as the bottom panel of Figure 1 attests.

\subsection{Defining and Measuring Informality}

Defining informal employment is a complex issue (see, e.g., Perry et al. 2007).We use the "legalistic" perspective to determine informal employment in this paper, i.e. we consider an employment

\footnotetext{
${ }^{10}$ For a discussion of the pros and cons of using survey data to define displacement see the introductory chapter in Kuhn (2002).

${ }^{11}$ In our opinion there certainly exist good arguments to consider job separations voluntary when they occur because of the expiring of a contract. When a worker signs a contract for a temporary job s/he does so out of her/his own volition. The separation resulting from such a contract can, therefore, be considered voluntary. The same can be said about a contract signed that has a probation period as one of its stipulations as long as the firm evaluates the worker's performance fairly.
} 
relationship informal if the employer does not register the job to avoid the payment of taxes and social security contributions. $^{12}$ The Russian labor code stipulates that all employees must sign a written contract and provide their "labor book" to the employer. Oral agreements are explicitly prohibited. We consider self-employed workers as informal if their activity is not registered. Also interesting, and thus far little pursued in the literature is informality that arises from "envelope payments”, where workers who are formally employed get part of their income as undeclared wages.

The main RLMS data survey instrument contains questions that allow the identification of workers who have informal employment relationships. Dependent employees are asked whether they are officially registered at their job, i.e. whether they are on a "work roster, work agreement or contract?" A positive response to this question is interpreted as a formal employment relationship. Those workers who say no to this question are considered to be in an informal employment relationship. For those who are determined to be in such a relationship we can also establish whether they entered it involuntarily or voluntarily. ${ }^{13}$ From the main data set we can also recover the percentage of a worker's salary that is paid officially, that is on which taxes and contributions are paid, thus indirectly establishing the incidence and extent of unofficial wage payments or so-called “envelope payments.”

The supplement on informality allows us to establish dependent workers who have an oral contract in 2009, which we take as a second measure of an informal employment relationship. The informality supplement also allows us to get at the issue of informal employment from an additional angle, by asking dependent employees whether to their knowledge the employer pays social security contributions on the entire wage or only on part of it. In the latter case the percentage of non-

\footnotetext{
12 The "productive" concept of informal employment, which for example links small firm size or self-employment to informal status can lead in transition economies to large measurement error (Lehmann and Pignatti 2007). This is not to say that the "legalistic" definition cannot be also plagued by some measurement error. In a middle income transition country like Russia this type of measurement error strikes us, however, as smaller of an order of magnitude than the measurement error associated with the "productive" definition.

${ }^{13}$ Respondents are asked whether (1) the employer did not want a registration of the job, (2) the respondent did not want to register, or (3) both employer and respondent did not want to register. Respondents giving answers (2) or (3) are deemed to be voluntarily in informal jobs.
} 
compliance is asked for. We use the answers to these questions to establish the incidence of informal employment. In addition, the displacement supplement contains retrospective questions about the type of contract, which a person has in the period 2003-2008. Again, we take the existence of an oral contract as an indication of an informal employment relationship

All information that we use to construct the informality measures is summarized in Table 2, where we also give the source and the way we use the data in the estimation. The first two measures, informal employment and informality in contributions, are taken from the informality supplement. The percentage of official wage payments, the complement of "envelope payments", is taken from the 2009 reference week section of the main RLMS data. The information that allows us to construct formal dependent employment as well as involuntary informal dependent employment and voluntary informal dependent employment (item 4) is also taken from the 2009 reference week section of the main RLMS data. To establish informal and formal self-employment we employ data from both the 2009 informality supplement and from the 2009 reference week section of the main RLMS data. This information and responses that imply non-employment in the 2009 reference week are the basis for the construction of six mutually exclusive labor market states, in which workers can find themselves in $2009 .{ }^{14}$ Finally, information from the displacement supplement is used to construct panel data on informal employment for the years 2003 to 2008, equating an oral contract with an informal employment relationship. We use the retrospective panel data from the displacement supplement since these data allow us to accurately map separation events to informality status.

\subsection{Job separations and destination labor market states: a descriptive analysis}

Table 3 shows the link between type of job separation, occurring anytime between 2003 and 2008, and the six labor market states, in which a worker can be found in 2009. Looking at displacement events,

\footnotetext{
${ }^{14}$ These states are: involuntary informal dependent employment, voluntary informal dependent employment, formal dependent employment, formal self-employment, informal self-employment and non-employment
} 
the bold numbers give the absolute number and the percentages of events associated with each destination state. For example, 35 displacement events in the years 2003-2008 (8.4\% of all displacement events in this period) are associated with non-employment in 2009. The vast majority of displacement events is unsurprisingly linked to dependent formal employment, while at a low level slightly more are associated with involuntary than voluntary informal dependent employment. Selfemployment is the least likely outcome for workers experiencing displacement, with formal selfemployment particularly rare, since of the total 416 displacement events only 2 are associated with formal self-employment in 2009. We see a similar distribution of quit events by destination state, with the vast majority of quits ending up in formal dependent employment and self-employment, in particular formal self-employment, being the least likely destination.

When we slice separation events along the formal-informal dimension the distribution of labor market states changes markedly. For example, comparing the distributions for quit events from formal and informal jobs we can see that the number of individuals ending up in dependent formal employment drops by more than 20 percentage points when we go from quitting formal jobs to quitting informal jobs. In addition, quits from formal jobs produce a slightly higher percentage of workers ending up as a voluntary informal employee while quitting from informal jobs is associated with a large majority of involuntary informal jobs within dependent informal employment. Similar changes in the distributions of destination states occur when going from formal to informal job displacement, with the caveat that the absolute numbers are small for the latter type of displacement. Our descriptive analysis clearly points to the persistence of informality and to the fact that some workers previously employed in an informal job seem to subsequently get entrapped in informal jobs against their will.

The third entry in each cell of Table 3 gives the ratio of separation events relative to the number of individuals in a destination state in 2009 together with their standard deviations. For example, the total 
displacement events associated with non-employment are 35 and the number of individuals in this state in 2009 are 104, leading to a ratio of 0.337 . The ratio of total quits to individuals in non-employment is 0.885. Going down the columns one can see the contribution of separation events of each type to the number of individuals in each state in 2009. Inspection of these ratios with respect to type of separation shows the obvious fact, that the contribution of quit events is much larger than the contribution of displacement events. Also note that the ratio of the total displacement and quit events are larger than the sum of their respective disaggregated events because of missing information regarding the distinction between formal and informal jobs. ${ }^{15}$

Finally, the sum of the total displacement and quit ratios tells us how much the stocks in the respective states are driven by job turnover brought on by displacement and quits. When this sum is less than 1, like, for example, in the case of the destination state of dependent formal employment (0.656) separations do not contribute to a rising stock of the state. In the case of the states of dependent involuntary and voluntary informal employment the sum of the ratios is far above 1 . This implies that displacement and quit events contribute to rising stocks of the two states in question. For informal and formal self-employment, the sums of the ratios are below 1. The upshot of these calculations is that displacement and quit events contribute disproportionately to the stocks of dependent informal employment, but not to informal self-employment.

\section{The empirical models and our research approach}

The decision to be an informal worker can be modeled in the framework of random utility models, where choices are determined by individual characteristics $x_{i}$ and an error term $\varepsilon$ which includes

\footnotetext{
${ }^{15}$ For the same reason in the last column of Table 3 total separation events are larger than the sum of these events originating from formal and informal jobs.
} 
unobserved attributes. An individual $i$ opts for informality if the utility from this choice, $U^{\text {inf }}$ is higher than the utility from a formal job, $U^{\text {form }}$. Thus, the probability of observing individual $i$ in an informal job is:

$$
\begin{aligned}
& \operatorname{Pr}(\operatorname{Inf}=1)=\operatorname{Pr}\left(U^{\text {inf }}>U^{\text {form }}\right)=\operatorname{Pr}\left(x_{i}{ }^{\prime} \beta^{\text {inf }}-x_{i}{ }^{\prime} \beta^{\text {form }}+\varepsilon_{i}^{\text {inf }}-\varepsilon_{i}^{\text {form }}>0\right) \\
& =\operatorname{Pr}\left(x_{i}{ }^{\prime} \boldsymbol{\beta}+\boldsymbol{\varepsilon}>0\right)=\Phi\left(x_{i}{ }^{\prime} \boldsymbol{\beta}\right)
\end{aligned}
$$

Assuming that the unobserved factors $\varepsilon$ are normally distributed, the binary choice between informality and formality can be estimated using a standard probit model.

We start by estimating the set of binary choice equations for different dependent variables in 2009 that define the informal employment relationship employing the probit model (1) as well as standard OLS regressions to estimate the complement of “envelope payments”, that is, the percentage of official wage payments. We begin with the most parsimonious model that includes exogenous covariates only (age and gender), and then extend it by including sequentially other covariates, which are summarized in Table 1. To at least reduce the omitted variables bias we also control for risk attitudes which are usually unobserved and found to be an important predictor of informality status (Dohmen, Khamis and Lehmann 2011). To this purpose we use a general risk indicator, which runs from 0 (complete unwillingness to take risks in general matters) to 10 (complete willingness to take risks in general matters). Inspection of Table 1 shows that on this measure a majority of employees are risk averse and that informal employees have a substantially higher propensity to take risks than formal employees.

The main regressors of interest are, of course, the measures related to job separations. We employ the number of displacement and quit events and link them to informality in $2009 .{ }^{16}$ These measures of job separations are defined for three different time intervals: job separations occurring in

\footnotetext{
16 The small number of displacements caused by firm or plant closure (see panel 2 of Figure 1) determines our research strategy insofar as we cannot use this measure as our conditioning variable, even though it is thought to be "more exogenoeus" than displacement due to redundancies. Instead, we have to employ displacement in general as our conditioning regressor, independent of whether it is due to firm/plant closure or redundancies.
} 
2008 (t-1), in 2007 and 2008 (t-2), and in the period 2003-2008. We thus model shorter-term and longer-term effects of job separations on informality, but also ensure that the coefficients on the separation variables in our cross section regressions do not just pick up the rising trend of informal employment and informality that we have mentioned in the introduction.

The sketched regressions that use probit and OLS models can establish correlations between separations and informality, they cannot establish a causal effect of the former on the latter. Assuming that the unobservable factors are fixed over time, the causal effect can be estimated when these unobservables are differenced away. We, therefore, take advantage of the panel dimension of our data, and, in a second step, estimate pooled logit and fixed effects logit models with the separation events occurring at time t-1 and t-2. The panel data are retrospective data covering the years 2003 to 2008, which might raise concerns of recall bias. Preliminary analysis of these retrospective data by Lehmann et al. (2011) shows that recall bias does not drive the results regarding wage developments. Considering that recall bias should be minimal when recalling such a dramatic event as a job separation we are confident that displacement and quits are measured essentially without error, or, if there should exist some measurement error, it will not be systematically correlated with informality.

The derivation of the fixed effects logit specification is more complex than the derivation of the probit or the pooled logit model. We estimate a conditional maximum likelihood on the sample of individuals who change status at least once over the 6 periods that we have at our disposal. For these individuals the conditional distribution of the sequence of outcomes does not depend on the individual specific and time-invariant unobserved effect (Wooldridge, 2002). As long the time invariance assumption of unobservable factors holds we can identify a causal effect of separations on informality status. In addition, we also perform robustness checks of the fixed effects logit model by interacting year dummies with region and year dummies with gender and educational attainment. In this way we, 
at least partially, can account for possible time-varying unobservable factors that have an impact on informality.

Taken together, the results of the probit, OLS, pooled logit and fixed effects logit regressions, estimated with the sample of dependent employees of working age (16-59), provide a tentative answer to the question whether the type of job separation matters for an informal relationship or "envelope payments” in subsequent jobs.

To obtain a better understanding of the voluntary versus involuntary nature of informality, in a last step, we differentiate between six different labor market states - formal employment, involuntary informal employment, voluntary informal employment, formal self-employment, informal selfemployment and non-employment. Again, random utility models can be used to estimate such multiple choice models. In this framework, the probability of observing outcome $\mathrm{j}$ is:

$$
\operatorname{Pr}\left(U^{j}>U^{k}\right) \text { for any } k \neq j
$$

If the $\mathrm{k}$ error terms have an extreme value distribution, this choice can be estimated using a multinomial logit model. This model is estimated with the cross-section data of 2009, where the set of regressors includes displacement and quit measures of separation events, which, however, can occur anytime in the period $2003-2008 .^{17}$ Estimation of multinomial logit models using the whole sample of the working age population allows us to give an answer to the question whether displaced workers are more likely to get entrapped in informal employment. Slicing the data by level of education and by source of separation (separation from formal or informal employment) we provide an empirical analysis of heterogeneous outcomes along observable characteristics. ${ }^{18}$

\footnotetext{
${ }^{17}$ We have also experimented with estimating pooled multinomial logit models for the 2003-2008 period in order to incorporate more labor market transitions and to check the robustness of our results. We were, however, not able to distinguish between voluntary and involuntary self-employment and had to use self-reported self-employment status in these regressions. The main results were qualitatively similar to the ones reported in the text and are available from the authors upon request.

${ }^{18}$ A major drawback of the multinomial logit model is the assumption that the error terms are mutually independent leading to the independence of irrelevant alternatives (IIA) property. We have conducted several tests excluding each of the outcomes (or a combination of more outcomes) and tested the IIA property between this restricted model and the full model
} 


\section{Results}

\subsection{Relation between separation events and informality status}

Using various measures of informal employment from different sources as well as the percentage of official wage payments as the dependent variables representing informality status in 2009, we perform probit and OLS regressions, having a set of control variables and separation (displacement and quit) events as the explanatory variables of interest. The set of separation events that we employ jointly in all our regressions is characterized according to the three different time intervals mentioned in the previous section. The results of this set of regressions will be summarized in a concise fashion by reporting the marginal effects on the separation measures. However, to better understand how we proceed we reproduce the results of probit regressions that link informal employment in 2009 to displacement and quit events occurring in 2008.

Table 4 shows the four specifications of this probit model. The first specification only includes truly exogenous covariates. It has a quadratic in age and gender, with older workers having a lower, while males having a higher probability to be in informal employment. Both results are confirmed in the scarce literature on informal employment in transition countries (Krstic and Sanfey 2007, Lehmann and Pignatti 2007, Bernabè and Stampini 2008, Pagés and Stampini 2007 and Gimpelson and Zudina 2011). Specification 2 adds variables of educational attainment, of marital status, for the number of children, for living in a village or in a big city. It also controls for local labor market conditions by including small region dummies. Workers living in a village or in a big city have a lower probability of being informally employed by roughly five percentage points than workers living in regional centers.

with all the alternatives. The IIA test was implemented with a generalized Hausman test. The null hypothesis of equality of coefficients between the restricted and full model was always rejected. For this reason, we have opted for the full efficient model which includes all outcomes. An alternative route would have been to estimate multinomial probit models, which alas is not possible with the data at hand since we do not have exclusion restrictions, i.e. attributes that vary across choices (see Keane, 1992, for identification requirements of multinomial probit models). The second theoretical alternative to the multinomial logit model could be the nested logit model. This model, while solving the IIA problem, in practice converges only in the context of a conditional logit model, i.e. a model where there exist characteristics which vary across choices. 
Confirming our priors, workers with higher education have a propensity to be informally employed that is substantially lower than workers with primary education or less. For workers with secondary education this negative difference in the propensity to be informally employed also exists but is attenuated. In the case of married workers this propensity is 2 percentage points lower. Specification 3 adds the general risk measure running from 0 (“unwilling to take any risk") to 10 ("always willing to take risk"). An increase by one unit of this measure will increase the likelihood of being in an informal employment relationship by roughly half a percentage point. This positive relationship between willingness to take risks and informal employment confirms the finding of Dohmen, Khamis and Lehmann (2011) who study the link between risk attitudes and informality in Ukraine. The final specification adds household income which is negatively related to informal employment, but is not statistically significant. ${ }^{19}$ We thus report the marginal effects of displacement and quit events of specification 3 when summarizing our regression results.

These marginal effects in Table 5 are large but attenuated over time when having an oral contract defines informal employment. A displacement event taking place in 2008 raises the probability of being informally employed by nearly 6 percentage points. This effect falls to roughly 2 percentage points if displacement occurs anytime in the period 2003-2008. The effects are smaller for quits but show the same attenuation pattern. If in the opinion of the employee the employer does not pay social security contributions or pays them only partially the worker is defined to be informally employed. Defining informal employment in this way produces very large marginal effects since displacement occurring in 2008 is associated with a rise of the probability of being informally employed of roughly 15 percentage points falling to about 7 percentage points when the displacement event falls into the 2003-2008 interval. For quits these effects are substantially smaller. The third block of results deals

\footnotetext{
${ }^{19}$ We performed some sensitivity analysis with this probit model, expanding the classification of displacement by including expiring of contract and of probation time in its definition. The results we very similar to those in Table 4 and are available upon request from the authors.
} 
with the complement of informal employment using the respondent's assertion that in the reference week of $2009 \mathrm{~s} / \mathrm{he}$ is officially registered at the job. While having the same attenuation patterns with respect to the time intervals as the other two measures, the effects are much smaller (in absolute value) and quits seem to produce a slightly larger reduction in formal employment than displacement events. The final block in panel 1 reports the coefficients on the separation events when the dependent variable is the percentage of officially paid wages. We have the striking result that the large negative effect on the percentage of official wage payments is not attenuated when we use the larger 2007-2008 interval. Attenuation only sets in when separation occurs anytime between 2003 and 2008. Equally striking are the much larger declines associated with displacement events.

Since we estimate the effects of displacement and quit events jointly we are able to test for the equality of the marginal effects. In the case of informal employment captured by a lack of paid contributions and in the case of official wage payments the null hypotheses of equal marginal effects or equal coefficients are rejected pointing to larger effects associated with displacement events. This assertion is particularly true for displacement events that have occurred in 2007 and 2008 and in the period 2003-2008. Even though the marginal effect of the displacement variable is substantially larger than the marginal effect of the quit variable when informal employment is defined as having an oral contract, the test fails to reject the null hypothesis of equal marginal effects. In the case of formal employment the marginal effects are quite close or even equal; consequently unsurprisingly the null hypothesis is not rejected in this case. ${ }^{20}$

The evidence presented in Table 5 provides some tentative answers to our first research question. Job separations are strongly associated with a higher incidence of informal employment no matter which of its measures we use. Job separations also lead to a substantial reduction in official wage

\footnotetext{
${ }^{20}$ The results of the chi-square tests (in the case of the probit regressions) and F-tests (when using OLS regression) are not shown here but available upon request from the authors.
} 
payments in subsequent jobs. In two of the four cases, informal employment captured by lack of paid contributions and the percentage of official wage payments, formal tests establish a larger effect for displacement events than for quits. So, displaced workers are more strongly affected by informal employment relationships and "envelope” payments in subsequent jobs than their quitting counterparts.

\subsection{Establishing a causal effect of separation events on informal employment}

The cross-section regressions that we performed thus far establish strong correlations between separation events and informality status, no matter which definition is used. We now take the analysis a step further using the retrospective panel data of the 2008 displacement supplement. This is a monthly data set with a complete labor market history of all respondents employed at time of interview, which allows us to identify displacement and quit events up to 12 months (t-1) and 24 months (t-2) prior to holding an employment relationship. This employment relationship, the dependent variable, is traced back through time, taking the value one if the respondent has an oral contract. We start off with the estimation of pooled logit models and then turn to fixed effects logit models to establish a causal effect of separation events on informal employment.

The first two columns of Table 6 present coefficients on the separation variables and other covariates including year dummies of the pooled logit model. A comparison with the marginal effects of the probit regressions in Table 4 shows the same demographic characteristics driving informal employment since the signs and the significance levels are similar. Displacement and quit events have large impacts on informal employment independent of whether we use t-1 or t-2 as the time interval. The larger coefficients on the quit variables are confirmed by formal tests that reject the null hypothesis of equal coefficients.

While the pooled logit model takes advantage of variation between and within individuals the fixed effects logit model only uses variation within individuals, i.e. only uses respondents who move from 
formality to informality and vice versa. The number of regressors is thus reduced with fixed effects logit estimation ${ }^{21}$, but we eliminate unobservable factors that partially determine informal employment as long as these unobservable factors are time-invariant.

The coefficients on the displacement variables in columns 3 and 4 are slightly larger than the corresponding coefficients in the pooled logit models. In contrast, the coefficients on quits fall dramatically in the fixed effects model. It is of particular interest that the impact of displacement events shows no attenuation when we go from 2008 to the period 2007 and 2008 and is nearly three times as large as the impact of quit events in this time period. Formal tests strongly confirm this larger impact of displacement on informal employment when we control for time-invariant unobserved effects. ${ }^{22}$

The estimates on the separation events in columns 3 and 4 of Table 6 are preserved when we perform robustness checks of this fixed effects model. As columns 1 and 2 of Table A2 in the appendix attest, the magnitudes of the coefficients on the displacement and quit measures are very similar to those in Table 6 when we add the interaction of year with region as an additional regressor. The magnitudes are also maintained if we add the interactions of year with education and with gender to the model (columns 3 and 4 of Table A2). Thus, when we partially take account of the variation in the macroeconomic environment over time and space as well as of time-varying heterogeneity, the baseline effect is clearly not altered.

The larger estimated effects of displacement events in the fixed effects logit model and the fact that these effects are not attenuated over time in conjunction with the smaller and attenuated effects of quit events might be interpreted as evidence of a segmented labor market. Essentially those separated from

\footnotetext{
${ }^{21}$ Adding year dummies in the fixed effects model wipes out the linear term of the quadratic in age. On the other hand, since some workers change education, the number of children and marital status over the span of the panel these variables are not eliminated from the set of regressors.

${ }^{22}$ We also estimated the pooled and the fixed effects logit models using the more encompassing definition of displacement. The estimated coefficients on the separation variables are very close to those in Table 6 . They are not reported but available on request.
} 
their jobs involuntarily seem to be rationed out of formal employment more than their quitting counterparts. Since we have information on the voluntary nature of informal dependent employment in our data we analyze this issue of labor market segmentation in what follows together with the question whether displacement imposes a cost on workers in the form of involuntary informal employment.

\subsection{Job separations and the involuntary and voluntary nature of informal employment}

Taking formal dependent employment as our base category, we perform multinomial logit (MNL) regressions varying measures of displacement and quits and allowing for five labor market states in addition to the state of formal employment of dependent workers: involuntary informal employment of dependent workers, voluntary informal employment of dependent workers, informal self-employment, formal self-employment and non-employment. We treat both informal self-employment and formal dependent employment as voluntary.

The six states shown in table 7 are given for the year $2009 .{ }^{23}$ The MNL regressions are cross section regressions where we estimate the probability of being in a certain state in 2009 using covariates from the same year, including the general risk indicator. The main regressors of interest are measures of job separations, which are defined as separations occurring anytime between 2003 and 2008. We use this time interval to maximize the number of occurring job separations. The evidence in table 5 implies that it is not really problematic to map separation events in the period 2003-2008 to labor market status in 2009 since the effects of displacement and quits are never reduced to 0 when we choose this longest time interval at our disposal. In addition the evidence of the fixed effects estimates in Table 6 points to a non-decreasing causal effect of displacement on informal employment as the time interval is widened to 24 months, while for quits the effect is only slightly reduced.

\footnotetext{
${ }^{23}$ We are confronted here with rather small sample sizes, especially for the formal and informal self-employed.
} 
On the basis of MNL regressions, not shown here but available on request, we calculate the marginal effects of displacement and quits for the six potential states. In panels 1-3 of Table 7, we use variants of the sum of displacement and quit events as the regressors of interest, while panel 4 is based on one MNL regression with four mutually exclusive dummies included: the dummies take the value one if the last separation is a displacement from an informal job, a displacement from a formal job, a quit from an informal job or a quit from a formal job.

In panel 1, both the sum of displacement events and the sum of quit events raise the probability of being involuntarily in informal employment by roughly half a percentage point. In contrast, only quits raise the probability of being in a voluntary informal job. We take these two results as evidence that displaced workers get trapped in informal jobs while among quitters there are some workers who select themselves into an informal job while others read the labor market wrong and end up involuntarily in such a job. Panel 1 also shows that those who separate voluntarily from their job lower their chances of finding formal dependent employment, while the displaced have a lower probability of being selfemployed formally. It is also striking that displaced workers have a far higher probability to end up in non-employment than those who quit.

Panel 2 shows displacement and quit events interacted with low and high education ${ }^{24}$. Displaced workers with low human capital find themselves with a higher probability in involuntary informal employment than their non-displaced counterparts, while displaced workers with high educational attainment are much less likely to find themselves in this state. While for both groups displacement does not affect the probability to be in voluntary informal employment, it has a positive impact on formal employment for the highly educated displaced workers. In turn displaced workers with low human capital have a lower propensity to end up in informal self-employment, while they have a larger

\footnotetext{
${ }^{24}$ High education means university education; low education is secondary education or less.
} 
probability to enter non-employment. The sum of quit events of workers with low and high education have a somewhat different pattern. Those with low education have an increased likelihood to be in both the involuntary and voluntary sector of dependent informal employment; at the same time these workers are less likely to find themselves in formal dependent and self-employment. Workers with high education who quit their previous jobs have a higher propensity of finding a voluntary informal job, and a substantially lower probability to be involved in informal self-employment, while the states involuntary informal and formal dependent employment are not affected by their quitting actions.

The evidence collected in panel 2 can be interpreted in the following way. Some of the workers with low human capital who are displaced get trapped in informal jobs, as they end up in a state they do not want to select. On the other hand, workers with a large amount of human capital upon displacement do not find themselves more frequently in any type of informal employment relationships; in actual fact, interacting displacement with high education depresses the probability to be in an involuntary informal job substantially. Workers with low education who quit end up in both involuntary and voluntary informal jobs, so some of them get trapped against their will in informal employment. In turn, workers well endowed with human capital who quit subsequently can avoid informal jobs if they do not want them. Consequently, the results presented in panel 2 imply that informal employment is an important cost of displacement and that it falls predominantly on workers with low education. At the same time, for quitters with low human capital the presented results imply some labor market segmentation.

In panel 3 displacement and quit events are sliced differently as we investigate whether there are differences in the probability of occupying states by formal or informal sector of origin. Concentrating on dependent employment as an outcome, we see that being displaced from a formal job does not affect any dependent employment state. Quits from formal employment, on the other hand, raise the 
probability to be in voluntary informal jobs. We find no effects on dependent informal employment for those workers who are displaced from an informal job. For those who quit from such a job the likelihood is raised for both involuntary and voluntary informal employment. It is also striking that those who quit from an informal job are not entering non-employment at an increased rate but informal and formal self-employment, while the three remaining separations in panel 3 cause a higher probability to end up in non-employment.

Panel 4, where the last separation is decomposed in four mutually exclusive events (displacement from a formal job, displacement from an informal job, quits form a formal job and quits from an informal job), conveys similar information as the previous panel. For example, quits from informal employment translate into higher probabilities of both types of informal jobs. In addition, displacement from an informal job makes it a lot less likely that the new job is of the voluntary informal nature.

\section{Conclusions}

The general research question that we investigate focuses on the link between job separations (displacement and quits) and informality. Our empirical analysis explores whether displaced workers and quitters experience more informal employment and “envelope payments” in subsequent jobs than new labor market entrants or incumbents. In a transition economy like the Russian one where informal employment has been growing and where the vast majority of incumbents has a formal employment relationship it might well be that the burden of rising informal employment falls disproportionately on job separators.

We refine this general research question by probing into the question whether workers who are involuntarily separated from their jobs are more likely to become trapped in involuntary informal employment than workers who quit their jobs. We also analyze whether this experience of potentially 
being trapped in involuntary informal employment differs by the level of human capital. In addition, we look at the persistence of informality, that is, whether past spells in informal employment raises the likelihood to be currently in an informal job.

Our central results confirm our contention that displacement entraps some of the workers in involuntary informal employment. Those who quit, in turn, experience voluntary informality for the most part, but there seems to be a minority of quitting workers who end up in involuntary informal jobs because they read the labor market wrong when separating from their previous job. However, this scenario of entrapment for the displaced and wrong expectations of some of those who quit does not fall on all the workers who separate but predominantly on workers with low human capital and on those who separate from informal jobs. This latter result also implies that informal employment is persistent as some workers churn from one informal job to the next. We also find strong evidence that displaced workers are confronted with a larger share of "envelope payments" in formal jobs than quitters.

Overall, our results point to informal employment as an important cost of job loss in the Russian labor market. In a companion paper on the monetary and non-monetary costs of displacement in the Russian labor market we put forth the policy recommendation to promote policies that help displaced workers to increase their search effectiveness. This recommendation was based on the fact that the main monetary costs of job loss were found to be foregone earnings due to long spells of nonemployment and not wage penalties upon re-employment. Given the results in this study, the policies that we wish to advocate need to be amended. If it is true that above all displaced workers with low human capital end up in informal jobs involuntarily, training and further training policies should also be on the agenda of policy makers who wish to help displaced workers. 


\section{References}

Albrecht, J., L. Navarro and S. Vroman (2009). The effects of labor market policies in an economy with an informal sector, Economic Journal, 119, 1105-1129.

Bernabè, S. and M. Stampini (2008). Labour mobility during transition: Evidence from Georgia.” LICOS Discussion Paper Series, Discussion Paper 206.

Boeri, T. and P. Garibaldi (2006) Shadow sorting, CEPR Discussion Paper 5487.

Bosch, M. and W.F. Maloney (2010). Comparative analysis of labor market dynamics using Markov processes: An application to informality, Labour Economics, 17 (4), 621-631.

De Soto, H. (1990). The other path: The invisible revolution in the Third World, Perennial Library.

Dohmen, T., M. Khamis and H. Lehmann (2011). Risk attitudes, time preferences and the incidence of informality among workers: Evidence from a transition country, Bonn and Maastricht, unprocessed.

Fields, G. S.(1990). Labour market modelling and the urban informal sector: theory and evidence.” in The Informal Sector Revisited. D. Thurnham, B. Salomé and A. Schwarz eds.: OECD. Paris.

Gimpelson, V. and A. Zudina (2011). The "informal” in the Russian economy: How many are there and who are they? Higher School of Economics Working Paper WP3/2011/06, Moscow (in Russian).

Harris, J.R. and M.P. Todaro (1970). Migration, unemployment and development: A two sector analysis, American Economic Review, 60, 126-142.

Hijzen, A., Upward R. and P. W. Wright (2010). The income losses of displaced workers, Journal of Human Resources, 45 (1), 243-269.

Keane, M.P. (1992). A note on identification in the multinomial probit model, Journal of Business \& Economic Statistics, 10 (2), 193-200.

Kolm, A.-S. and B. Larsen (2003). Social norm, the informal sector and unemployment, Finanzarchiv, 59, 407-424.

Krstic, G. and P. Sanfey (2007). Mobility, poverty and well-being among the informally employed in Bosnia and Herzegovina, Economic Systems, 31(3), 311-335.

Kuhn, P. - Ed. (2002). Losing Work, Moving On: Worker Displacement, an International Perspective, W. E. Upjohn Institute for Employment Research.

Lehmann, H. and N. Pignatti (2007). Informal employment and labor market segmentation in transition economies: Evidence from Ukraine, IZA Discussion Paper 3269.

Lehmann,H., A. Muravyev, T. Razzolini and A. Zaiceva (2011). The wage and non-wage costs of displacement: Evidence from Russia, Department of Economics Working Paper 734, University of Bologna, March.

Leombruni, R., T. Razzolini, and F. Serti (2010). The pecuniary and non-pecuniary costs of job displacement. The risky job of getting back to work. Ivie Working Paper WP-AD 2010-12.

Lindo, J.M. (2011). Parental job loss and infant health, Journal of Health Economics, 30 (5), 869-879.

Liu, H. and Z. Zhao (2011). Parental job loss and children's health: Ten years after the massive layoff of the SOE’s workers in China, IZA Discussion Paper No. 5846, July.

Maloney, W. F. (2004). Informality Revisited. World Development, 32, 1159-1178. 
Pagés, C. and M. Stampini (2007). No education, no good jobs? Evidence on the relationship between education and labor market segmentation, IZA Discussion Paper No. 3187.

Perry, G., Maloney, W., Arias, O., Fajnzylber, P., Mason, A., and Saavedra-Chanduvi, J. (2007). Informality: Exit and Exclusion. Washington, DC: World Bank.

Pissarides, C. (1994). Search unemployment with on-the-job search, Review of Economic Studies 61 (3), 457-475.

Schneider, F., A. Buehn and C. E. Montenegro (2010). Shadow economies all over the world: New estimates for 162 Countries from 1999 to 2007. World Bank, mimeo.

Sullivan, D. and T. von Wachter (2009). Job displacement and mortality: An analysis using administrative data, Quarterly Journal of Economics 124 (3), 1265-1306.

United States Bureau of Labor Statistics - U.S.BLS (2010). Extended Mass Layoffs in 2009, Report 1025, Department of Labor, Washington D.C., December.

Wooldridge, J. M. (2002). Econometric Analysis of Cross Section and Panel Data, MIT Press, Cambridge, MA and London, England.

Zenou, Y. (2008). Job search and mobility in developing countries: theory and policy implications, Journal of Development Economics, 86, 336-355. 


\section{FIGURES}

\section{Figure 1: Separations and Layoffs}

Separations (sample: w orking age $15-59$ years)

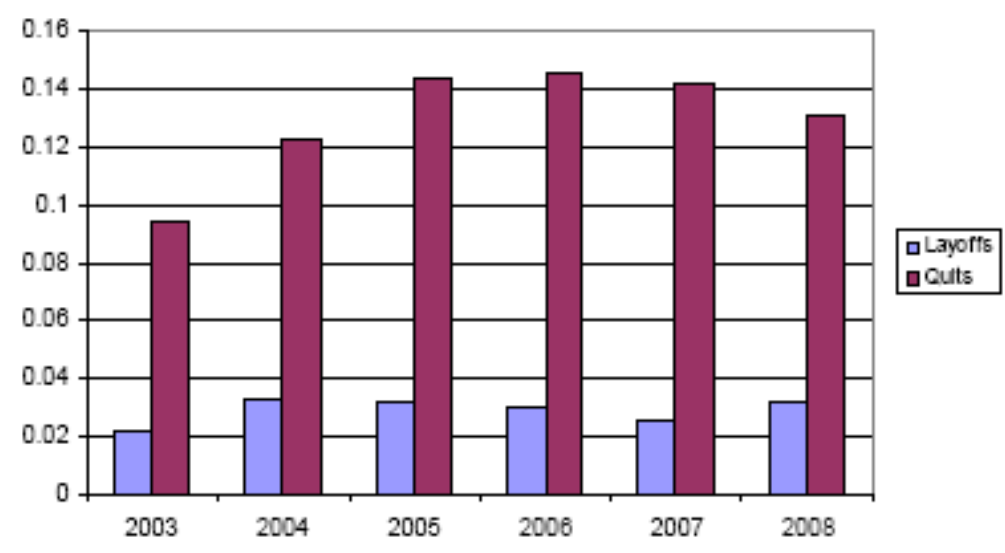

Layoffs (sample: w orking age $15-59$ years)

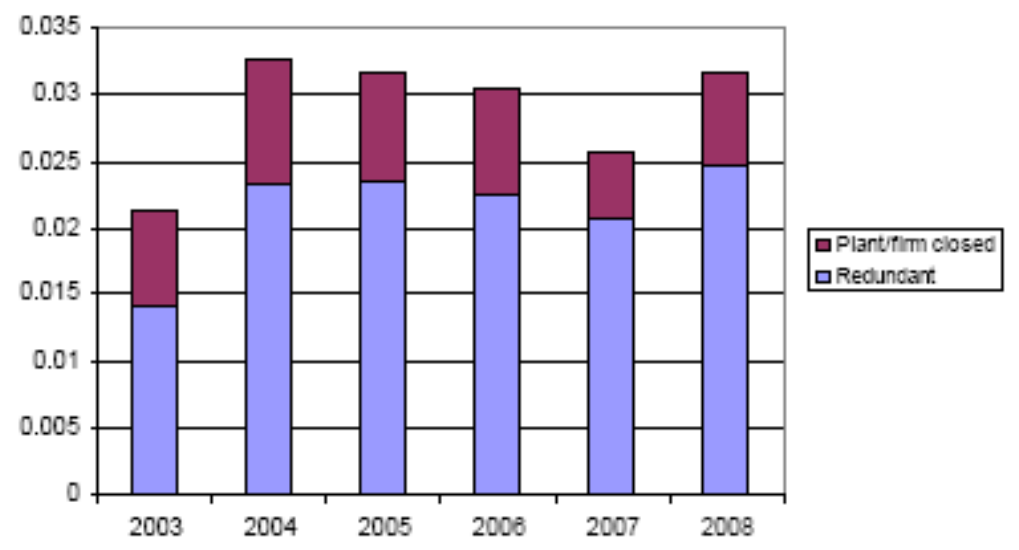

Source: Authors' calculations based on RLMS supplement on displacement.

Note: Our definition of working age deviates from the official definition, which is 16-59 for men and 16-54 for women. 


\section{TABLES}

Table 1: Descriptive statistics of dependent employees

\begin{tabular}{|c|c|c|c|}
\hline Variables & All sample & Employed officially & Informal Employees \\
\hline Displ., 2008 & $0.025(0.155)$ & $0.022(0.146)$ & $0.041(0.199)$ \\
\hline Displ., 2007-2008 & $0.042(0.211)$ & $0.039(0.205)$ & $0.066(0.249)$ \\
\hline Displ., 2003-2008 & $0.134(0.394)$ & $0.122(0.376)$ & $0.231(0.511)$ \\
\hline Quits, 2008 & $0.095(0.306)$ & $0.086(0.291)$ & $0.248(0.469)$ \\
\hline Quits, 2007-2008 & $0.198(0.473)$ & $0.184(0.457)$ & $0.413(0.626)$ \\
\hline Quits, 2003-2008 & $0.585(0.917)$ & $0.551(0.881)$ & $1.116(1.180)$ \\
\hline Months non-empl., 2008 & $0.438(1.844)$ & $0.352(1.637)$ & $1.471(3.310)$ \\
\hline Months non-empl., 2007-2008 & $1.020(3.771)$ & $0.841(3.367)$ & $3.008(6.736)$ \\
\hline Months non-empl., 2003-2008 & $2.626(8.253)$ & $2.225(7.459)$ & $7.058(13.625)$ \\
\hline Age & $42.714(9.130)$ & $42.897(9.091)$ & $41.554(9.324)$ \\
\hline Male & $0.431(0.495)$ & $0.423(0.494)$ & $0.537(0.499)$ \\
\hline City & $0.344(0.475)$ & $0.346(0.476)$ & $0.256(0.437)$ \\
\hline Village & $0.190(0.393)$ & $0.185(0.389)$ & $0.165(0.372)$ \\
\hline Regional center & $0.466(0.499)$ & $0.469(0.499)$ & $0.579(0.494)$ \\
\hline Higher education & $0.291(0.454)$ & $0.309(0.462)$ & $0.116(0.320)$ \\
\hline Secondary education & $0.622(0.485)$ & $0.609(0.488)$ & $0.736(0.441)$ \\
\hline Primary education & $0.087(0.282)$ & $0.081(0.273)$ & $0.149(0.356)$ \\
\hline Children & $0.735(0.787)$ & $0.731(0.788)$ & $0.719(0.742)$ \\
\hline Marital status & $0.806(0.395)$ & $0.810(0.392)$ & $0.760(0.427)$ \\
\hline Moscow/St. Petersburg & $0.182(0.385)$ & $0.186(0.389)$ & $0.264(0.441)$ \\
\hline North-West & $0.069(0.253)$ & $0.072(0.259)$ & $0.017(0.128)$ \\
\hline Central-Volga & $0.432(0.495)$ & $0.431(0.495)$ & $0.339(0.474)$ \\
\hline South & $0.106(0.308)$ & $0.102(0.303)$ & $0.099(0.299)$ \\
\hline East & $0.212(0.409)$ & $0.209(0.406)$ & $0.281(0.450)$ \\
\hline Risk indicator & $3.744(2.816)$ & 3.657 (2.789) & $4.372(2.733)$ \\
\hline Household income & 33402.91 (22074.41) & 33656.14 (22044.56) & 33449.59 (23522.41) \\
\hline N. obs & 16854 & 15342 & 726 \\
\hline
\end{tabular}

Notes: Sample used in the analysis with the 2009 data. "Official Employment" variable is from the main survey. "Displ." and "Quits" stand for sum of separation events. Household income includes total income of the family in the last 30 days and is trimmed (the first and the last percentage is dropped); the sample for the household income is 15702. 
Table 2: Informality measures

\begin{tabular}{|c|c|c|}
\hline Measure of informality & Source & $\begin{array}{l}\text { Way data are used in } \\
\text { estimations }\end{array}$ \\
\hline $\begin{array}{l}\text { 1) Informal employment } \\
\text { Equals } 1 \text { if employee has an oral agreement without } \\
\text { documents. }\end{array}$ & $\begin{array}{l}\text { Informality supplement } \\
2009\end{array}$ & Cross-section \\
\hline $\begin{array}{l}\text { 2) Informality in contributions: } \\
\text { Equals } 1 \text { if the employer does not or is suspected not to } \\
\text { pay, at least in part, the social security contributions } \\
\text { commensurate with an employee's wage. }\end{array}$ & $\begin{array}{l}\text { Informality supplement } \\
2009\end{array}$ & Cross-section \\
\hline $\begin{array}{l}\text { 3) Percentage of official wage: } \\
\text { Denotes the percentage of the wage the respondent } \\
\text { thinks was paid officially, i.e. from which the employer } \\
\text { paid taxes (set equal to missing if answer is “don’t } \\
\text { know"). }\end{array}$ & $\begin{array}{l}\text { Main survey } 2009 \\
\text { Reference week section }\end{array}$ & Cross-section \\
\hline $\begin{array}{l}\text { 4) Formal dependent employment plus voluntary nature } \\
\text { thereof: } \\
\text { 4a) Equals } 1 \text { if an employee is registered at the job } \\
\text { officially, that is with labour book/agreement or } \\
\text { contract. } \\
\text { 4b) if informal dependent employment: Voluntary vs. } \\
\text { involuntary: } \\
\text { Involuntary informal equals } 1 \text { if the employer didn't } \\
\text { want to register, while voluntary informal - if either } \\
\text { employee or both employer and employee didn't want } \\
\text { to register. }\end{array}$ & $\begin{array}{l}\text { Main survey } 2009 \\
\text { Reference week section }\end{array}$ & Cross section \\
\hline $\begin{array}{l}\text { 5) Informal and formal self-employment: } \\
\text { if the respondent works in an enterprise or organization, } \\
\text { is the owner of the firm and considers himself as an } \\
\text { entrepreneur and is not officially registered at the job (it } \\
\text { is formal if the respondent is registered at the job) }\end{array}$ & $\begin{array}{l}\text { Informality supplement } \\
2009 \text { and Main survey } \\
2009 \text { Reference week } \\
\text { section }\end{array}$ & Cross section \\
\hline $\begin{array}{l}\text { 6) informal employment: } \\
\text { Equals } 1 \text { if employee has an oral agreement without } \\
\text { documents. }\end{array}$ & $\begin{array}{l}\text { Displacement } \\
\text { supplement } 2008\end{array}$ & $\begin{array}{l}\text { Retrospective panel } \\
\text { 2003-2008 }\end{array}$ \\
\hline
\end{tabular}


Table 3: Descriptive statistics on types of separations and potential destination states

\begin{tabular}{|c|c|c|c|c|c|c|c|}
\hline \multirow[b]{2}{*}{$\begin{array}{l}\text { Type of job } \\
\text { separation } \\
2003-2008\end{array}$} & \multicolumn{7}{|c|}{ Destination state in 2009} \\
\hline & $\begin{array}{c}0 \\
\text { Non- } \\
\text { employed. }\end{array}$ & $\begin{array}{c}1 \\
\text { Formal } \\
\text { employee }\end{array}$ & $\begin{array}{c}2 \\
\text { Informal } \\
\text { Involuntary } \\
\text { employee }\end{array}$ & $\begin{array}{c}\text { } 3 \\
\text { Informal } \\
\text { Voluntary } \\
\text { Employee }\end{array}$ & $\begin{array}{c}4 \\
\text { Self- } \\
\text { employed } \\
\text { informal }\end{array}$ & $\begin{array}{c}5 \\
\text { Self- } \\
\text { employed } \\
\text { formal }\end{array}$ & \\
\hline $\begin{array}{c}\text { Displacement } \\
\text { events total }\end{array}$ & $\begin{array}{c}\mathbf{3 5} \\
\mathbf{8 . 4 \%} \\
0.337 \\
(0.601) \\
\end{array}$ & $\begin{array}{c}342 \\
82.2 \% \\
0.119 \\
(0.370)\end{array}$ & $\begin{array}{c}\mathbf{1 5} \\
\mathbf{3 . 6 \%} \\
0.234 \\
(0.496)\end{array}$ & $\begin{array}{c}13 \\
\mathbf{3 . 1 \%} \\
0.220 \\
(0.527)\end{array}$ & $\begin{array}{c}\mathbf{9} \\
\mathbf{2 . 2 \%} \\
0.076 \\
(0.297)\end{array}$ & $\begin{array}{c}\mathbf{2} \\
\mathbf{0 . 5 \%} \\
0.039 \\
(0.196)\end{array}$ & $\begin{array}{c}416 \\
100 \%\end{array}$ \\
\hline $\begin{array}{c}\text { Displacement } \\
\text { events from } \\
\text { formal job }\end{array}$ & $\begin{array}{c}\mathbf{3 2} \\
\mathbf{8 . 7 \%} \\
0.308 \\
(0.576) \\
\end{array}$ & $\begin{array}{c}\mathbf{3 0 4} \\
\mathbf{8 2 . 8 \%} \\
0.106 \\
(0.349) \\
\end{array}$ & $\begin{array}{c}12 \\
3.3 \% \\
0.187 \\
(0.467) \\
\end{array}$ & $\begin{array}{c}12 \\
3.3 \% \\
0.203 \\
(0.518) \\
\end{array}$ & $\begin{array}{c}\mathbf{6} \\
\mathbf{1 . 6 \%} \\
0.051 \\
(0.221) \\
\end{array}$ & $\begin{array}{c}\mathbf{1} \\
\mathbf{0 . 2 \%} \\
0.019 \\
(0.140) \\
\end{array}$ & $\begin{array}{c}367 \\
100 \%\end{array}$ \\
\hline $\begin{array}{c}\text { Displacement } \\
\text { events from } \\
\text { informal job }\end{array}$ & $\begin{array}{c}3 \\
\mathbf{1 2 . 5 \%} \\
0.029 \\
(0.168)\end{array}$ & $\begin{array}{c}\mathbf{1 7} \\
\mathbf{7 0 . 8 \%} \\
0.006 \\
(0.085)\end{array}$ & $\begin{array}{c}\mathbf{2} \\
\mathbf{8 . 3 \%} \\
0.0312 \\
(0.175)\end{array}$ & $\begin{array}{c}\mathbf{1} \\
\mathbf{4 . 2 \%} \\
0.017 \\
(0.130)\end{array}$ & $\mathbf{0}$ & $\begin{array}{c}1 \\
\mathbf{4} .2 \% \\
0.020 \\
(0.140)\end{array}$ & $\begin{array}{c}24 \\
100 \%\end{array}$ \\
\hline $\begin{array}{c}\text { Quit events } \\
\text { total }\end{array}$ & $\begin{array}{c}\mathbf{9 2} \\
\mathbf{5 \%} \\
0.885 \\
(0.884)\end{array}$ & $\begin{array}{c}\mathbf{1 5 4 6} \\
\mathbf{8 3 . 2 \%} \\
0.537 \\
(0.869)\end{array}$ & $\begin{array}{c}\mathbf{7 1} \\
\mathbf{3 . 8 \%} \\
1.109 \\
(1.311)\end{array}$ & $\begin{array}{c}65 \\
3.5 \% \\
1.102 \\
(1.029)\end{array}$ & $\begin{array}{c}\mathbf{6 2} \\
\mathbf{3 . 2 \%} \\
0.525 \\
(1.115)\end{array}$ & $\begin{array}{c}22 \\
\mathbf{1 . 2 \%} \\
0.431 \\
(0.806)\end{array}$ & $\begin{array}{r}1858 \\
100 \%\end{array}$ \\
\hline $\begin{array}{l}\text { Quit events } \\
\text { from formal } \\
\text { job }\end{array}$ & $\begin{array}{c}\mathbf{7 9} \\
\mathbf{5 \%} \\
0.760 \\
(0.876)\end{array}$ & $\begin{array}{c}\mathbf{1 3 5 3} \\
\mathbf{8 5 . 6 \%} \\
0.470 \\
(0.791)\end{array}$ & $\begin{array}{c}43 \\
2.7 \% \\
0.672 \\
(0.855)\end{array}$ & $\begin{array}{c}\mathbf{5 1} \\
\mathbf{3 . 2 \%} \\
0.864 \\
(0.798)\end{array}$ & $\begin{array}{c}39 \\
\mathbf{2 . 5 \%} \\
0.331 \\
(0.693)\end{array}$ & $\begin{array}{c}\mathbf{1 6} \\
\mathbf{1 \%} \\
0.314 \\
(0.678)\end{array}$ & $\begin{array}{c}1581 \\
100 \%\end{array}$ \\
\hline $\begin{array}{c}\text { Quit events } \\
\text { from informal } \\
\text { job }\end{array}$ & $\begin{array}{c}\mathbf{9} \\
\mathbf{5 . 5 \%} \\
0.087 \\
(0.315)\end{array}$ & $\begin{array}{c}\mathbf{1 0 5} \\
\mathbf{6 3 . 6 \%} \\
0.037 \\
(0.229)\end{array}$ & $\begin{array}{c}22 \\
\mathbf{1 3 . 3 \%} \\
0.344 \\
(0.930)\end{array}$ & $\begin{array}{c}\mathbf{1 1} \\
\mathbf{6 . 6 \%} \\
0.184 \\
(0.473)\end{array}$ & $\begin{array}{c}13 \\
7.9 \% \\
0.110 \\
(0.429)\end{array}$ & $\begin{array}{c}\mathbf{5} \\
\mathbf{3 \%} \\
0.098 \\
(0.361)\end{array}$ & $\begin{array}{c}165 \\
100 \%\end{array}$ \\
\hline & & mber of $i$ & iduals in & ective st & 2009) & & \\
\hline & 104 & 2879 & 64 & 59 & 118 & 51 & 3275 \\
\hline
\end{tabular}

Notes: In the top of each cell we find in bold the total number of type of separation event by potential destination state and its percentage relative to the total number of that event in the entire sample. The second row gives the distribution of individuals in the labor market states in 2009 for the main job. The third row displays the ratio of type of separation event by potential destination state relative to the number of individuals in this destination state in 2009 (N.B.: These are events not individuals. i.e. an individual might be displaced more than once, and all these events enter the ratio.) Standard deviations are in parentheses. N.B. The sum of displacement events from formal jobs and from informal jobs does not equal the total number of displacements because of missing information on formality/informality in some cases. The same problem exists with quits. 
Table 4: The impact of displacement and quit events occurring in 2008 on informal employment in 2009 - Probit regressions - marginal effects

\begin{tabular}{lcccc}
\hline & $(1)$ & $(2)$ & $(3)$ & $(4)$ \\
\hline Displ. & $0.048^{* * *}$ & $0.074^{* * *}$ & $0.057^{* * *}$ & $0.052^{* * *}$ \\
& $(0.013)$ & $(0.016)$ & $(0.014)$ & $(0.015)$ \\
Quits & $0.054^{* * *}$ & $0.040^{* * *}$ & $0.041^{* * *}$ & $0.046^{* * *}$ \\
& $(0.004)$ & $(0.004)$ & $(0.004)$ & $(0.004)$ \\
Age & $-0.008^{* * *}$ & $-0.006^{* * *}$ & $-0.005^{* * *}$ & $-0.006^{* * *}$ \\
& $(0.001)$ & $(0.001)$ & $(0.001)$ & $(0.001)$ \\
Age squared & $0.000^{* * *}$ & $0.000^{* * *}$ & $0.000^{* * *}$ & $0.000^{* * *}$ \\
& $(0.000)$ & $(0.000)$ & $(0.000)$ & $(0.000)$ \\
Male & $0.025^{* * *}$ & $0.022^{* * *}$ & $0.019^{* * *}$ & $0.016^{* * *}$ \\
& $(0.003)$ & $(0.003)$ & $(0.003)$ & $(0.003)$ \\
City & & $-0.061^{* * *}$ & $-0.059^{* * *}$ & $-0.060^{* * *}$ \\
& & $(0.019)$ & $(0.019)$ & $(0.020)$ \\
Village & & $-0.052^{* * *}$ & $-0.049^{* * *}$ & $-0.047^{* * *}$ \\
& & $(0.011)$ & $(0.011)$ & $(0.012)$ \\
Higher edu. & & $-0.051^{* * *}$ & $-0.050^{* * *}$ & $-0.048^{* * *}$ \\
& & $(0.003)$ & $(0.003)$ & $(0.004)$ \\
Sec. edu. & & $-0.022^{* * *}$ & $-0.019 * * *$ & $-0.015^{* * *}$ \\
& & $(0.005)$ & $(0.005)$ & $(0.005)$ \\
Children & & -0.001 & -0.001 & 0.001 \\
& & $(0.002)$ & $(0.002)$ & $(0.002)$ \\
Married & & $-0.020^{* * *}$ & $-0.022^{* * *}$ & $-0.015^{* * *}$ \\
& & $(0.005)$ & $(0.005)$ & $(0.005)$ \\
Risk indicator & & & $0.004^{* * *}$ & $0.005^{* * *}$ \\
& & & $(0.000)$ & $(0.001)$ \\
Hh. income & & & -0.000 \\
& & & & $(0.000)$ \\
Small regions & & & yes & yes \\
Observations & 22116 & 17442 & 16854 & 15432 \\
\hline
\end{tabular}

Source of dependent variable: Informality supplement in 2009. Robust standard errors in parentheses.

* significant at $10 \%$; ** significant at $5 \%$; ** significant at $1 \%$. 
Table 5: Relation between different informality measures and separation events

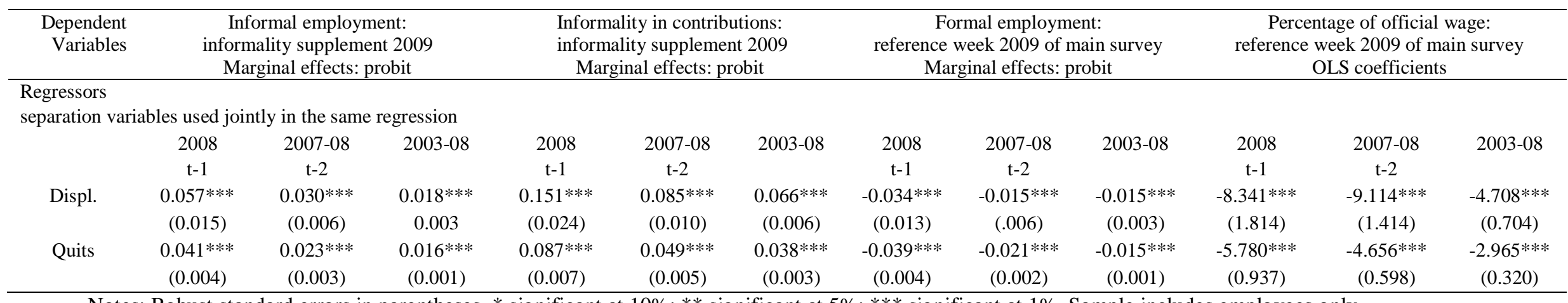

Notes: Robust standard errors in parentheses. * significant at $10 \%$; ** significant at $5 \%$; *** significant at $1 \%$. Sample includes employees only.

"Displ." and "Quits" stand for sum of separation events. All regressions include age, age squared, gender, city/village dummies, education, children,

marital status, risk indicator and small regions (primary sample units). The tests of the equality of marginal effects or coefficients suggest that they are statistically different for informality in contributions and percentage of official wage, but not in the case of having an oral contract or being registered at the job oficially. The means of the dependent variables are as follows: informal employment - 0.060 , informality in contributions - 0.143 , formal employment - 0.948, Percentage of official wage - 89.469 . 
Table 6: Pooled and Fixed Effects logit regressions

\begin{tabular}{|c|c|c|c|c|}
\hline & \multirow{2}{*}{\multicolumn{2}{|c|}{ Pooled logit }} & \multicolumn{2}{|r|}{ (4) } \\
\hline & & & \multicolumn{2}{|c|}{ FE logit } \\
\hline & $\mathrm{t}-1$ & $\mathrm{t}-2$ & $\mathrm{t}-1$ & $\mathrm{t}-2$ \\
\hline Displ. & $\begin{array}{c}0.437 * * * \\
(0.040)\end{array}$ & & $\begin{array}{c}0.532 * * * \\
(0.074)\end{array}$ & \\
\hline Quits & $\begin{array}{c}0.718^{* * *} \\
(0.028)\end{array}$ & & $\begin{array}{c}0.310^{* * *} \\
(0.048)\end{array}$ & \\
\hline Displ. & & $\begin{array}{c}0.510 * * * \\
(0.034)\end{array}$ & & $\begin{array}{c}0.634 * * * \\
(0.070)\end{array}$ \\
\hline Quits & & $\begin{array}{c}0.772 * * * \\
(0.027)\end{array}$ & & $\begin{array}{c}0.233 * * * \\
(0.053)\end{array}$ \\
\hline Age & $\begin{array}{c}-0.128 * * * \\
(0.007)\end{array}$ & $\begin{array}{c}-0.115 * * * \\
(0.007)\end{array}$ & & \\
\hline Age squared & $\begin{array}{c}0.001^{* * *} \\
(0.000)\end{array}$ & $\begin{array}{c}0.001 * * * \\
(0.000)\end{array}$ & $\begin{array}{c}0.006^{* * *} \\
(0.001)\end{array}$ & $\begin{array}{c}0.007 * * * \\
(0.001)\end{array}$ \\
\hline Male & $\begin{array}{c}0.283^{* * *} \\
(0.020)\end{array}$ & $\begin{array}{c}0.293 * * * \\
(0.020)\end{array}$ & & \\
\hline Higher edu & $\begin{array}{c}-1.827 * * * \\
(0.039)\end{array}$ & $\begin{array}{c}-1.816 * * * \\
(0.039)\end{array}$ & $\begin{array}{c}-2.394 * * * \\
(0.300)\end{array}$ & $\begin{array}{c}-2.424 * * * \\
(0.299)\end{array}$ \\
\hline Sec. edu. & $\begin{array}{c}-0.538 * * * \\
(0.025)\end{array}$ & $\begin{array}{c}-0.530 * * * \\
(0.025)\end{array}$ & $\begin{array}{c}0.094 \\
(0.142)\end{array}$ & $\begin{array}{c}0.054 \\
(0.142)\end{array}$ \\
\hline Children & $\begin{array}{c}-0.043 * * * \\
(0.016)\end{array}$ & $\begin{array}{c}-0.043 * * * \\
(0.016)\end{array}$ & $\begin{array}{c}-0.349 * * * \\
(0.079)\end{array}$ & $\begin{array}{c}-0.380 * * * \\
(0.080)\end{array}$ \\
\hline Married & $\begin{array}{c}-0.328 * * * \\
(0.023)\end{array}$ & $\begin{array}{c}-0.339 * * * \\
(0.023)\end{array}$ & $\begin{array}{c}0.058 \\
(0.102)\end{array}$ & $\begin{array}{c}0.077 \\
(0.102)\end{array}$ \\
\hline North/West & $\begin{array}{c}0.000 \\
(0.047)\end{array}$ & $\begin{array}{c}0.017 \\
(0.047)\end{array}$ & & \\
\hline Central/Volga & $\begin{array}{c}0.300 * * * \\
(0.031)\end{array}$ & $\begin{array}{c}0.307 * * * \\
(0.031)\end{array}$ & & \\
\hline South & $\begin{array}{c}0.372 * * * \\
(0.041)\end{array}$ & $\begin{array}{c}0.366 * * * \\
(0.041)\end{array}$ & & \\
\hline East & $\begin{array}{c}0.614^{* * *} \\
(0.032)\end{array}$ & $\begin{array}{c}0.610 * * * \\
(0.032)\end{array}$ & & \\
\hline City & $\begin{array}{c}-0.514^{* * *} \\
(0.023)\end{array}$ & $\begin{array}{c}-0.513 * * * \\
(0.023)\end{array}$ & & \\
\hline Village & $\begin{array}{c}-0.805^{* * *} \\
(0.026)\end{array}$ & $\begin{array}{c}-0.807 * * * \\
(0.026)\end{array}$ & & \\
\hline Constant & $\begin{array}{c}-0.806 * * * \\
(0.146)\end{array}$ & $\begin{array}{c}-1.214 * * * \\
(0.148)\end{array}$ & & \\
\hline Year dummies & yes & yes & yes & yes \\
\hline Observations & 295070 & 295070 & 18335 & 18335 \\
\hline $\begin{array}{l}\text { N. of } \\
\text { Individuals }\end{array}$ & & & 349 & 349 \\
\hline
\end{tabular}

Robust standard errors in parentheses. * significant at 10\%; ** significant at 5\%; *** significant at $1 \%$.

The test of equality of coefficients of "Displ. and "quits" is rejected with all specifications. In the pooled logit the coefficients on "Displ.” are always significantly smaller than the coefficients on "Quits” (at t-1 and t-2). In the FE logit the coefficients on "Displ." are always significantly larger than the coefficients on “Quits”.

The dependent variable is informal employment (oral contract) and is taken from the displacement supplement 2008. "Displ.” and "Quits” stand for sum of separation events. This is a monthly dataset based on the retrospective panel from the displacement supplement; $\mathrm{t}-1$ indicates displacement or quit events in the previous 12 months; $\mathrm{t}-2$ indicates displacement or quit events in the previous 24 months. Fixed effects (Conditional) Logit estimation uses only job changers (i.e. movers from formality to informality and vice versa). Omitted categories: female, primary education, not married, regional center, Moscow/St. Petersburg. 


\section{Table 7: Multinomial logit regressions - marginal effects of regressors measuring displacement and quits}

\begin{tabular}{|c|c|c|c|c|c|c|}
\hline & $\begin{array}{l}\text { Involuntary } \\
\text { informal } \\
\text { employment }\end{array}$ & $\begin{array}{c}\text { Voluntary } \\
\text { informal } \\
\text { employment }\end{array}$ & $\begin{array}{c}\text { Formal } \\
\text { employment }\end{array}$ & $\begin{array}{l}\text { Informal self- } \\
\text { employment }\end{array}$ & $\begin{array}{l}\text { Formal self- } \\
\text { employment }\end{array}$ & $\begin{array}{c}\text { Non- } \\
\text { employment }\end{array}$ \\
\hline \multicolumn{7}{|c|}{ Panel 1: Displacements and quits used jointly } \\
\hline Displ. & $0.0049 *$ & 0.0035 & -0.0085 & -0.0125 & $-0.0094 *$ & $0.0219 * * *$ \\
\hline Quits & $0.005 * * *$ & $0.0043 * * *$ & $-0.0139 * * *$ & -0.0016 & -0.0018 & $0.0081 * * *$ \\
\hline \multicolumn{7}{|c|}{ Panel 2: Displacements and quits by education used jointly } \\
\hline Displ_low & $0.0049 * *$ & 0.0029 & -0.0056 & $-0.0146 *$ & -0.0109 & $0.0233 * * *$ \\
\hline Displ_high & $-0.1157 * * *$ & 0.0077 & $0.0897 * * *$ & 0.0089 & -0.0060 & 0.0154 \\
\hline Quits_low & $0.0043 * * *$ & $0.0039 * * *$ & $-0.0106 * *$ & 0.0010 & $-0.0057 * *$ & $0.0071 * * *$ \\
\hline Quits_high & 0.0009 & $0.0073 * * *$ & 0.0021 & $-0.0257 * * *$ & 0.0016 & $0.0138 * * *$ \\
\hline \multicolumn{7}{|c|}{ Panel 3: Displacements and quits by informality used jointly } \\
\hline Displ_formal & 0.0040 & 0.0044 & 0.0005 & $-0.0176 * *$ & $-0.0143 *$ & $0.0230 * * *$ \\
\hline Quits_formal & 0.0018 & $0.0039 * * *$ & -0.0027 & $-0.0092 * *$ & -0.0033 & $0.0094 * * *$ \\
\hline Displ_informal & 0.0139 & 0.0048 & -- & -- & 0.0126 & $0.0373 * *$ \\
\hline Quits_informal & $0.0142 * * *$ & $0.0090 * * *$ & $-0.0599 * * *$ & $0.0215 * * *$ & $0.0083 * * *$ & 0.0070 \\
\hline \multicolumn{7}{|c|}{ Panel 4: last separation by informality status used jointly } \\
\hline last_displ_formal & 0.0024 & 0.0192 & $-0.07 * * *$ & $-0.017 * * *$ & $-0.0093 * * *$ & $0.0748 * * *$ \\
\hline last_quit_formal & 0.0054 & $0.0152 * * *$ & $-0.0359 * * *$ & $-0.0172 * * *$ & $-0.0025^{* *}$ & $0.035 * * *$ \\
\hline last_displ_informal & 0.0679 & $-0.101 * * *$ & -0.1768 & $-0.0269 * * *$ & $-0.0038 * * *$ & 0.1497 \\
\hline last_quit_informal & $0.0449 *$ & $0.0571^{*}$ & $-0.166^{* * *}$ & 0.0033 & 0.007 & 0.0535 \\
\hline
\end{tabular}

Notes: Robust standard errors in parentheses. *significant at $10 \%$; **significant at $5 \%$; ${ }^{* * *}$ significant at $1 \%$. Marginal effects are reported.

“--" refers to the cells where the effects were estimated very imprecisely due to negligible numbers of observations.

Other covariates include age, age squared, gender, city, village, education, children, marital status, macro region and risk indicator.

Measures representing various types of separations:

"Displ.” and "Quits” stand for sum of separation events over 2003-2008.

"Displ_low” (“Quits_low”) and “Displ_high” (“Quits_high”) stands for the sum of displacement (quits) events for individuals with low (high) education, respectively.

“Displ_formal” (“Quits_formal”) and "Displ_informal” ("Quits_informal”) stand for the sum of displacement (quit) events from a formal and informal job, respectively.

"last_displ_formal” ("last_quit_formal”) and "last_displ_informal” ("last_quit_informal”) are equal to one if last separation is displacement (quit) from a formal or informal job, respectively; these four dummies represent mutually exclusive events. 


\begin{tabular}{|c|c|}
\hline REASON & CLASSIFICATION \\
\hline 1 Closing down of enterprise/organization & Displacement \\
\hline 2 Moving of enterprise/organization & Displacement \\
\hline 3Reorganization of enterprise/organization & Displacement \\
\hline 4 Bankruptcy of enterprise/organization & Displacement \\
\hline 5 Privatization of enterprise/organization & Displacement \\
\hline 6 Dismissal initiated by employer & Displacement \\
\hline 7 Personnel reduction & Displacement \\
\hline 8 Expiring of employment contract & Quit \\
\hline 9 Expiring of probation time & Quit \\
\hline 10 Military service & Quit \\
\hline 11 Imprisonment & Quit \\
\hline 12 Own illness or injury & Quit \\
\hline 13 Studies & Quit \\
\hline 14 Retirement & Quit \\
\hline 15 Early retirement & Quit \\
\hline 16 Marriage & Quit \\
\hline 17 Parental leave & Quit \\
\hline 18 Need to take care of other members of family & Quit \\
\hline 19 Change of residence & Quit \\
\hline 20 Wanted/was proposed higher salary & Quit \\
\hline 21 Wanted/was proposed better working conditions & Quit \\
\hline 22 Wanted/was proposed more interesting work & Quit \\
\hline 23 Wanted to start own business & Quit \\
\hline 24 Main job became second job & Quit \\
\hline 25 End of farming/sole proprietorship & Quit \\
\hline 26 Other & Variable \\
\hline
\end{tabular}


Table A2: Fixed Effects logit with interactions

\begin{tabular}{|c|c|c|c|c|}
\hline & (1) & (2) & (3) & (4) \\
\hline Displ. t-1 & $\begin{array}{c}0.549 * * * \\
(0.075)\end{array}$ & & $\begin{array}{c}0.523 * * * \\
(0.075)\end{array}$ & \\
\hline Quits t-1 & $\begin{array}{c}0.296 * * * \\
(0.048)\end{array}$ & & $\begin{array}{c}0.290 * * * \\
(0.048)\end{array}$ & \\
\hline Displ. t-2 & & $\begin{array}{c}0.685 * * * \\
(0.071)\end{array}$ & & $\begin{array}{c}0.612 * * * \\
(0.071)\end{array}$ \\
\hline Quits t-2 & & $\begin{array}{c}0.219 * * * \\
(0.054)\end{array}$ & & $\begin{array}{c}0.205^{* * *} \\
(0.054)\end{array}$ \\
\hline Year dummies & yes & yes & yes & yes \\
\hline Year×region & yes & yes & & \\
\hline Year×male & & & yes & yes \\
\hline Year×education & & & yes & yes \\
\hline Observations & 18335 & 18335 & 18335 & 18335 \\
\hline Number of ind. & 349 & 349 & 349 & 349 \\
\hline
\end{tabular}

Notes: Robust standard errors in parentheses. *significant at $10 \%$; **significant at $5 \%$;

$* * *$ significant at $1 \%$.

The dependent variable is informality (oral contract) from displacement supplement 2008.

"Displ." and "Quits” stand for sum of separation events.

This is a monthly dataset based on the retrospective panel from displacement supplement.

$\mathrm{t}-1$ indicates displacement or quit events in the previous 12 months, $\mathrm{t}-2$ indicates

displacement or quit events in the previous 24 months.

Fixed Effects (Conditional) Logit estimation uses only job changers (i.e. movers from

formality to informality and vice versa).

The rest of covariates is as in Table 6. 